\title{
CONGENITAL TALIPES EQUINOVARUS: I. RESOLVING AND RESISTANT DEFORMITIES
}

\author{
R. W. PORTER
}

From Doncaster Royal Infirmary

\begin{abstract}
Comparisons were made between 54 children with resolving congenital talipes equinovarus deformity and 81 children whose feet required surgical correction. There was a significant difference in the incidence of bilateral deformity, sex ratio and family history of congenital talipes in the two groups.

The children with resolving deformity had feet which were indistinguishable from the normal side of unilaterally affected children in their calf muscle measurements at six weeks of age, and in the range of movement and radiographs at four years of age. Those requiring surgery had varying degrees of muscle reduction, and although often well corrected, had a reduced range of movement and altered joint anatomy at four years of age. This suggests that they are two distinct populations.
\end{abstract}

Clinicians usually distinguish between those children whose congenital talipes equinovarus deformity is an isolated condition and those who have other anomalies (Wynne-Davies 1964; Turco 1971; Ippolito and Ponseti 1980). For the majority of children, the deformity of the foot is a single problem. It varies in degree, but it is not known whether this spectrum of severity includes one or more different pathologies. Harrold and Walker (1983) described three types of congenital talipes, "mild", "moderate" and "severe", depending on the degree of the original deformity, and stated that this was related to the prognosis. Hooker (1985) distinguished four types from their response to treatment. Others have used the terms "severe", "resistant", "mild" and "postural" (Attenborough 1966; Blockey and Smith 1966; Denham 1967; Tachdjian 1985).

In a personal series of children with equinovarus deformity, comparisons have been made between those whose deformity resolved with conservative management and those requiring surgical correction, to determine whether they were two distinct populations with different pathologies.

\section{METHOD}

Initially all the feet were treated conservatively. The majority were positioned in plaster, and attempts were made to improve the correction by changing the plaster at weekly intervals. The feet were not manipulated nor were they forcibly stretched, lest this resulted in a spurious correction or iatrogenic fibrosis. In a few the

R. W. Porter, MD, FRCS, FRCS Ed, Consultant Orthopaedic Surgeon Doncaster Royal Infirmary, Armthorpe Road, Doncaster DN2 5LT, England.

(C) 1987 British Editorial Society of Bone and Joint Surgery $0301-620 \mathrm{X} / 87 / 5144 \$ 2.00$ deformity was so mild that it was left to resolve without treatment. The feet were assessed at six weeks of age: if the calcaneus was high in the heel pad of fat, this was considered an indication for surgery (Fig. 1).

The children whose deformity resolved spontaneously or with serial plaster correction were compared with those treated surgically, recording the bilateral incidence, sex distribution, position in the family, maternal age, method of delivery, gestational age, birth weight, and any family history of congenital talipes. The severity of the deformity at birth recorded photographically and the calf muscle measured radiographically at six weeks of age were compared in the two populations. The neonatal foot was photographed from the anteromedial aspect at the level of the ankle, in order to superimpose the forefoot on the line of the tibia (Fig. 2). The angle subtended by the forefoot on the tibia was expressed as the angle of forefoot supination.

At six weeks of age a lateral soft-tissue radiograph was taken with the foot positioned in about $20^{\circ}$ of medial rotation to superimpose the posterior cortex of the lower

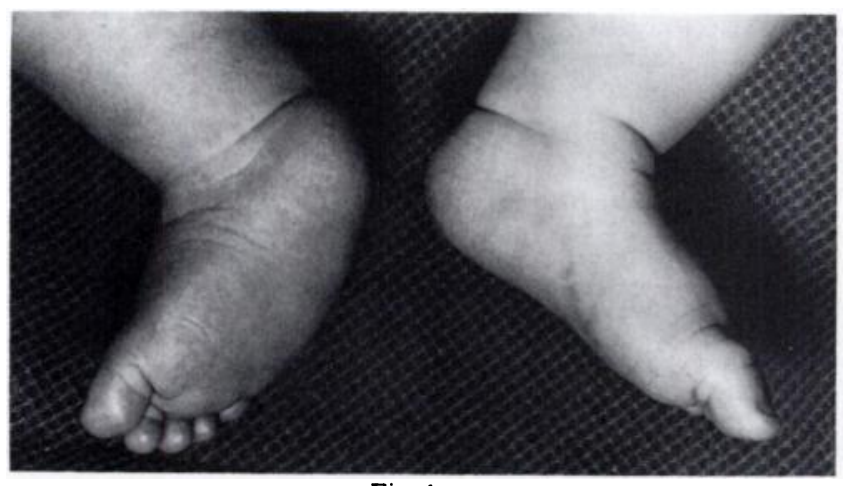

Fig. 1

Uncorrected right talipes equinovarus at 6 weeks of age, with abnormal contour, and the calcaneus still high in the heel pad of fat. 


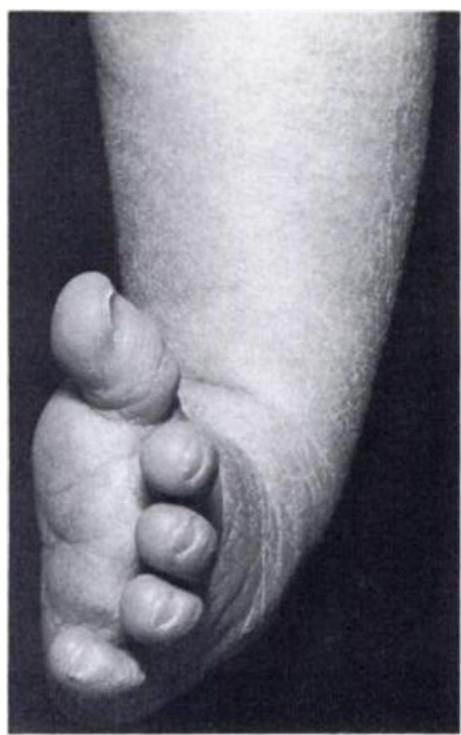

Fig. 2

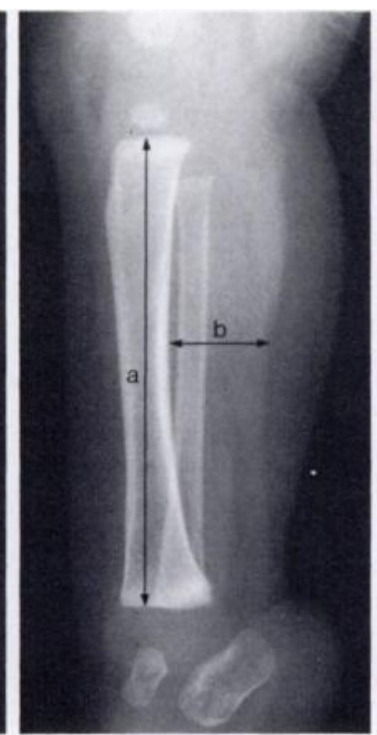

Fig. 3

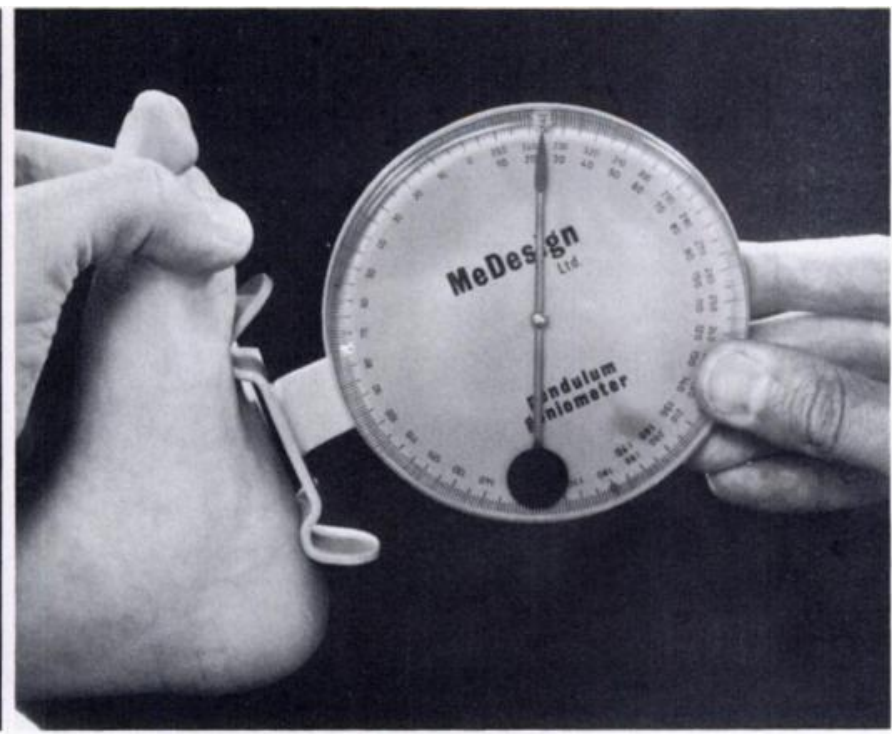

Fig. 4

The three measurements taken of the deformity. Figure 2 - Neonatal photograph of an equinovarus foot showing $90^{\circ}$ of forefoot supination. Figure 3 - Lateral calf radiograph taken at 6 weeks superimposing the posterior cortex of the lower fibula on that of the lower tibia. Muscle bulk is expressed as $a / b$ where $a$ is the length of the tibia and $b$ the distance between the gastrocnemius-soleus junction and the posterior tibial cortex. Figure 4 - Passive ankle dorsiflexion measured by goniometer at 4 years of age.

fibula on the posterior cortex of the lower tibia. The length of the tibia was then expressed as a ratio of the distance from the gastrocnemius-soleus junction to the posterior cortex of the tibia (Fig. 3).

At four years of age comparisons were made between the range of passive ankle movement, measured by goniometer (Fig. 4), and the degree of resting forefoot adduction and passive abduction. They were also assessed radiographically measuring Beatson's combined talo-calcaneal angle (Beatson and Pearson 1966) the talo-navicular angle (Main and Crider 1978), the navicular to first metatarsal angle (Lowe and Hannon 1973) and the tibio-talar angle (Simons 1985); the navicular, however, was not always ossified at four years of age. Those children who had a flexor accessorius longus muscle in the lower calf were compared with the remainder of the surgically treated children who, apart from reduction in muscle bulk, had normal calf anatomy.

\section{RESULTS}

There were 178 children born in Doncaster with equinovarus deformity between 1970 and $1985 ; 154$ had no other abnormality. The deformity resolved in 67 children, but 87 required surgical correction. In the two groups, 13 and six children respectively were lost to follow-up.

The incidence of bilateral deformity was significantly different in the two groups, $61 \%$ of the children whose feet responded to conservative management having bilateral deformity, compared with $44 \%$ of the operated group (Table I). The sex ratio also differed, with more girls responding to conservative treatment and more boys requiring surgery. Nine per cent of the surgically treated children had first-degree relatives with congenital talipes, whilst none of the children with resolving deformities had first-degree relatives affected.

The birth weight, gestational period, maternal age, method of delivery and percentage of first-born and subsequent children were not significantly different in the two groups, and were similar to those of the general population.

The mean resting forefoot supination at birth in the feet whose deformity resolved was $56.4^{\circ} \pm 20.7^{\circ}$ whilst in

Table I. Comparisons between children whose equinovarus deformities resolved and those who required surgical correction

\begin{tabular}{|c|c|c|c|}
\hline & $\begin{array}{l}\text { Surgery } \\
\text { needed }\end{array}$ & $\begin{array}{l}\text { Deformity } \\
\text { resolved }\end{array}$ & $\begin{array}{l}\text { General } \\
\text { population* }\end{array}$ \\
\hline Number of children & 81 & 54 & \\
\hline Bilateral incidence & $44^{\circ}$ & $6 I^{\circ}$ & \\
\hline Male & $67^{\circ}$ & $37^{\circ}$ & \\
\hline $\begin{array}{l}\text { Position in the family } \\
\text { First born } \\
\text { Second } \\
\text { Third plus }\end{array}$ & $\begin{array}{l}48^{\circ} \\
27^{\circ} \\
25^{\circ}\end{array}$ & $\begin{array}{l}46^{\circ} \\
33^{\circ} \\
21^{\circ}\end{array}$ & $\begin{array}{l}42^{\circ} \\
37^{\circ} \\
2 I^{\circ}\end{array}$ \\
\hline Mean maternal age (years) & 25.6 & 23.7 & 25.0 \\
\hline Mean birth weight $(\mathrm{kg})$ & 3.19 & 3.23 & 3.23 \\
\hline Mean gestation period (weeks) & 38.9 & 39.3 & 39.0 \\
\hline $\begin{array}{l}\text { Percentage of children whose first- } \\
\text { degree relatives had congenital talipes }\end{array}$ & 9.0 & Nil & \\
\hline $\begin{array}{l}\text { Method of delivery } \\
\text { Normal } \\
\text { Assisted } \\
\text { Caesarian section } \\
\text { Breech }\end{array}$ & $\begin{array}{l}73^{\circ} \\
14^{\circ} \% \\
8 \% \\
5 \%\end{array}$ & $\begin{array}{l}83 \% \\
9^{\circ} \\
6 \% \\
2 \%\end{array}$ & $\begin{array}{l}71^{\circ} \\
15^{\circ} \\
9^{\circ} \% \\
5 \%\end{array}$ \\
\hline
\end{tabular}

* South Yorkshire 1979-85 
Table II. Measurements of deformity in the two groups compared to normal feet (means and standard deviations)

\begin{tabular}{llll}
\hline & $\begin{array}{l}\text { Surgery } \\
\text { needed } \\
n=114\end{array}$ & $\begin{array}{l}\text { Deformity } \\
\text { resolved } \\
n=82\end{array}$ & $\begin{array}{l}\text { Normal side } \\
\text { of unilaterally } \\
\text { affected } \\
n=67\end{array}$ \\
\hline Forefoot supination at birth (degrees) & $90.0 \pm \frac{12.4}{\mathrm{p}<0.01} \begin{array}{c}56.4 \pm 20.7 \\
\mathrm{p}<0.01\end{array}$ & $\begin{array}{c}18.2 \pm 21.4 \\
\text { Tibia/calf muscle ratio at } 6 \text { weeks of age }\end{array}$ \\
\hline
\end{tabular}

Table III. Clinical and radiographic assessments of 135 children followed up at 4 years of age (means and standard deviations)

\begin{tabular}{|c|c|c|c|}
\hline & $\begin{array}{l}\text { Surgery } \\
\text { needed } \\
n=76\end{array}$ & $\begin{array}{l}\text { Deformity } \\
\text { resolved } \\
n=44\end{array}$ & $\begin{array}{l}\text { Normal side } \\
\text { of unilaterally } \\
\text { affected } \\
n=46\end{array}$ \\
\hline \multicolumn{4}{|l|}{ Clinical assessments (degrees) } \\
\hline Dorsiflexion & $18.9 \pm 10.2$ & $36.0 \pm 16.7$ & $38.2 \pm 12.1$ \\
\hline Plantarflexion & $33.3 \pm 13.3$ & $53.0 \pm 11.4$ & $50.5 \pm 7.9$ \\
\hline Resting adduction & $9.5 \pm 7.2$ & $5.6 \pm 6.3$ & $3.3 \pm 6.2$ \\
\hline Passive abduction & $14.3 \pm 4.2$ & $19.0 \pm 5.3$ & $19.2 \pm 8.3$ \\
\hline \multicolumn{4}{|c|}{ Radiographic assessment (degrees) } \\
\hline Beatson's combined angle & $58.5 \pm 20.5$ & $72.6 \pm 15.8$ & $73.0 \pm 15.4$ \\
\hline Talo-navicular angle & $87.7 \pm 15.2$ & $101.0 \pm 14.4$ & $102.0 \pm 16.5$ \\
\hline Naviculo-metatarsal angle & $77.3 \pm 16.7$ & $78.3 \pm 13.3$ & $75.0 \pm 12.1$ \\
\hline Tibio-talar angle & $37.4 \pm 13.8$ & $36.7 \pm 10.5$ & $34.2 \pm 10.0$ \\
\hline
\end{tabular}

those feet which required operative correction it was $90^{\circ} \pm 12.4^{\circ}$ (Table II and Fig. 5). Calf muscle measurements in the conservatively managed children did not differ significantly from the measurements on the normal side of those unilaterally affected, whilst in the operated children the calf muscle reduction was highly significant (Fig. 6)

Subsequent assessment of the children who had reached four years of age, failed to show any significant difference between the feet managed conservatively and

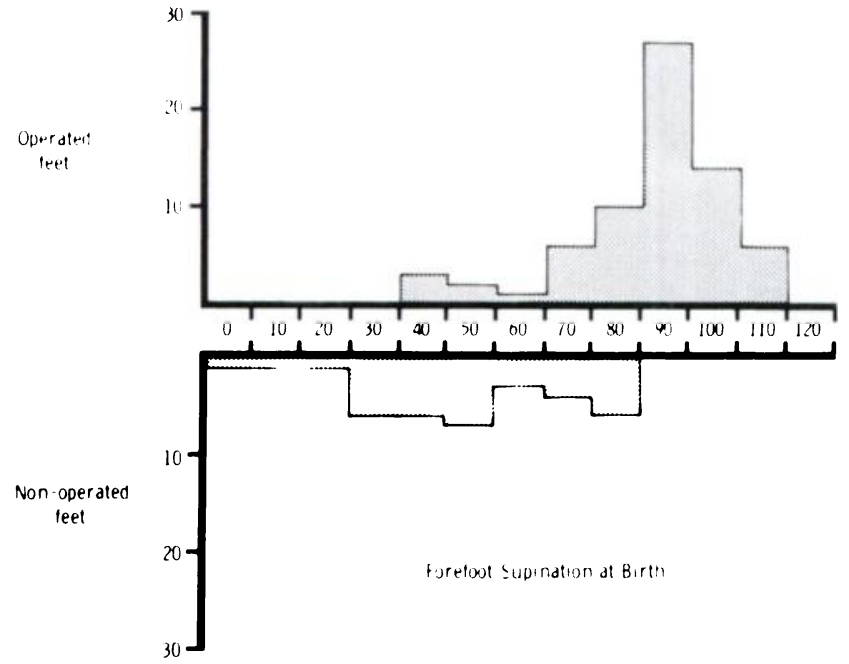

Fig. 5

Histogram showing the degrees of forefoot supination at birth in the feet requiring surgery, and in the non-operated feet. the normal feet of those with unilateral talipes. However, the clinical and radiographic measurements of the operated feet, often well corrected, showed distinct differences in range of movement and in joint anatomy from the normal side and from those treated conservatively (Table III). Five children had abnormal musculotendinous anatomy in the lower calf, with a flexor accessorius longus muscle (Turco 1979). There were no apparent differences between this small group and the remainder of the surgically treated children (Table IV).

\section{DISCUSSION}

These results support a distinction between resistant and resolving talipes. There was an intrinsic structural problem in the children whose feet required a surgical correction: they had reduction of the calf muscle at six weeks of age; and even after the feet were generally well corrected by surgery, the range of movement at the ankle remained reduced and the joint anatomy was abnormal. By contrast, the conservatively managed children had muscle measurements at six weeks within the normal range, and at subsequent assessment their feet were indistinguishable from unaffected feet in both their range of movement and in joint anatomy.

The mechanism of resolving deformities is compatible with a positional problem, the feet being tightly packed in utero, with a mild deformity which resolves after birth (Browne 1959). Pressure discoloration was sometimes visible on the posterolateral aspect of these feet at birth, lending support to this hypothesis (Wynne- 
Davies 1964). The two groups had a similar obstetric history but the absence of any family history in the children with resolving deformities, and the difference in bilateral numbers and sex incidence (Harrold and Walker 1983) supports there being two distinct populations.

Children with structural talipes are not necessarily a homogenous population; several different pathologies

Table IV. Children with a flexor accessorius longus muscle

\begin{tabular}{ll}
\hline Number & 5 \\
Unilateral & 3 \\
Male & 3 \\
First born & 2 \\
Mean maternal age & 22 years \\
Mean birth weight & $3.75 \mathrm{~kg}$ \\
Mean gestation period & 40.2 weeks \\
$\begin{array}{l}\text { First-degree relatives with congenital } \\
\text { talipes }\end{array}$ & 1 \\
Normal delivery & 5 \\
\hline
\end{tabular}

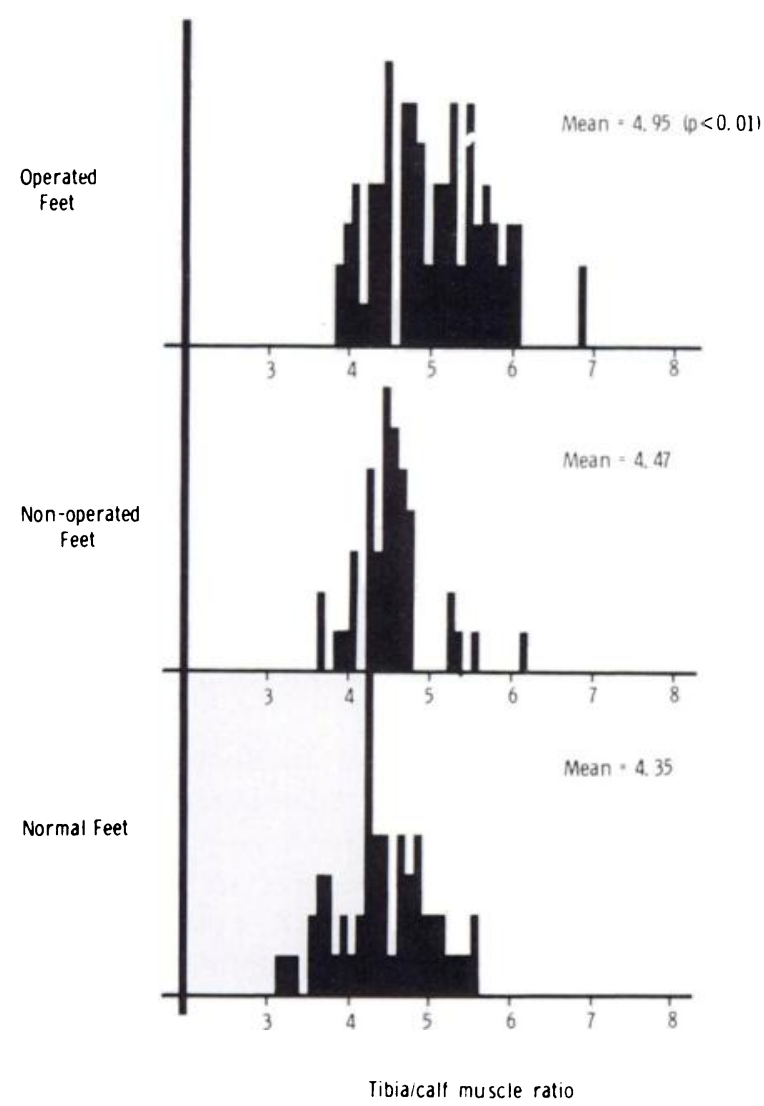

Fig. 6

Histogram showing the ratio of tibial length to distance from calf muscle at 6 weeks of age, in the children whose feet required surgery, in those with resolving deformity and in the opposite limbs of the unilaterally affected feet. (Significance between operated and resolving feet, $\mathrm{p}<0.001$ ) may produce the same deformity. A few children have abnormal musculotendinous anatomy (Grogono and Jowsey 1965) but there were no distinguishing features about the five in this series with an accessory flexor muscle. Some have talocalcaneal coalition (Turco 1979) and others soft-tissue laxity (Kite 1930; Carter and Sweetnam 1958; Wynne-Davies 1964), but this series was not large enough to identify the relative importance of these subgroups.

A distinction between the two types of congenital talipes, the resolving talipes and the structural deformity, is of considerable importance. Unless we identify the resolving deformity, the incidence of talipes in time and location will vary with the referring pattern of paediatricians. In addition, assessment of the results of treatment should exclude the resolving talipes, lest these feet which are ultimately indistinguishable from normal add a favourable bias to the series. With some justification we could reserve the term "congenital talipes equinovarus" for those feet with an intrinsic structural problem, and exclude those with a resolving deformity.

\section{REFERENCES}

Attenborough CG. Severe congenital talipes equinovarus. $J$ Bone Joint Surg $[B \boldsymbol{B r}] 1966: 48-\mathrm{B}: 31-9$.

Beatson TR, Pearson JR. A method of assessing correction in club feet. $J$ Bone Joint Surg [Br] 1966:48-B:40-50.

Blockey NJ, Smith MGH. The treatment of congenital club foot. J Bone Joint Surg [Br] 1966:48-B:660-5.

Browne D. The pathology and classification of talipes. Aust NZ J Surg 1959:29:85-91.

Carter C, Sweetnam R. Familial joint laxity and recurrent dislocation of the patella. J Bone Joint Surg [Br] 1958:40-B:664-7.

Denham RA. Congenital talipes equinovarus. J Bone Joimt Surg [Br] 1967;49-B:583

Grogono BJS, Jowsey J. Flexor accessoreus longus : an unusual muscle anomaly. J Bone Joint Surg [Br] 1965;47-B:118-9.

Harrold AJ, Walker CJ. Treatment and prognosis in congenital club foot. J Bone Joint Surg [Br] 1983;65-B:8-11.

Hooker CH. A club foot philosophy. J Bone Joint Surg [Br] $1985 ; 67-B: 490$.

Ippolito E, Ponseti IV. Congenital club foot in the human fetus: a histological study. J Bone Joint Surg [Am] 1980:62-A:8-22.

Kite JH. Non-operative treatment of congenital club feet : review of 100 cases. South Med J 1930:23:337-45.

Lowe LW, Hannon MA. Residual adduction of the forefoot in treated congenital club foot. J Bone Joint Surg [Br] 1973:55-B:809 13.

Main BJ, Crider RJ. An analysis of residual deformity in club feet submitted to early operation. $J$ Bone Joint Surg $[\mathrm{Br}]$ $1978: 60-B: 536-43$.

Simons GW. Complete subtalar release in club feet. Part II. Comparison with less extensive procedures. J Bone Joint Surg [Am] 1985:67-A:1056-65.

Tachdjian MO. The child's foot. Philadelphia, etc: WB Saunders, 1985.

Turco VJ. Surgical correction of the resistant club foot: one-stage posteromedial release with internal fixation: a preliminary report. J Bone Joint Surg [Am] 1971:53-A :477-97.

Turco VJ. Resistant congenital club foot - one stage posteromedial release with internal fixation: a follow-up report of a fifteen-year experience. J Bone Joint Surg [Am] 1979:61-A:805-14.

Wynne-Davies R. Family studies and the cause of congenital club foot talipes equinovarus, talipes calcaneo-valgus and metatarsus varus. J Bone Joint Surg [Br] 1964;46-B:445-63. 